\title{
The trophic link between squid and the emperor penguin Aptenodytes forsteri at Pointe Géologie, Antarctica
}

\author{
Ilka Zimmer · Uwe Piatkowski - Thomas Brey
}

Received: 20 February 2007 / Accepted: 27 June 2007

(C) Springer-Verlag 2007

\begin{abstract}
Cephalopod beaks retrieved from stomachs of dead emperor penguin chicks at Pointe Géologie, Terre Adélie, provide information on taxonomic and size composition of the penguin's squid diet, on the trophic range of the squid species preyed upon and on the fractional trophic impact of the penguin on the whole food web. Emperor penguins prey upon four squid species (Psychroteuthis glacialis, Kondakovia longimana, Gonatus antarcticus, Alluroteuthis antarcticus) and do not take squid larger than $480 \mathrm{~mm}$ mantle length. Larger squid live either below the penguin's diving range or are beyond its handling capacity. Nitrogen stable isotope ratios indicate that squids cover a range of about two trophic levels $\left(2.5-8 \%{ }_{0} \delta^{15} \mathrm{~N}\right)$. The impact of the emperor penguin, however, concentrates on the upper part of this range, about $68 \%$ of its squid prey being $>6 \% \delta^{15} \mathrm{~N}$. The principal components of the emperor's diet, fish, krill and squid, differ distinctly in average trophic level. Consequently the trophic position of the emperor penguin changes accordingly with diet composition and may differ by almost one trophic level between different emperor penguin colonies.
\end{abstract}

Communicated by M. Wahl.

I. Zimmer $(\bowtie) \cdot$ T. Brey

Alfred Wegener Institute for Polar and Marine Research,

PO Box 120161, 27515 Bremerhaven, Germany

e-mail: izimmer@awi-bremerhaven.de

U. Piatkowski

Leibniz-Institut für Meereswissenschaften Kiel, Düsternbrooker

Weg 20, 24105 Kiel, Germany

\section{Introduction}

Cephalopods play an important role in the ecology of the Southern Ocean, having been identified as key species in the diets of many higher predators, including penguins, various seabird species, seals, cetaceans and fish (Collins and Rodhouse 2006 and References therein). Cephalopod beak samples from predator stomachs provide information on the trophic position of cephalopods in the Antarctic food web and on their migration patterns and ontogenetic dietary shifts (Cherel and Hobson 2005). Therefore, studies of predator diet and foraging are a major source of information on Southern Ocean cephalopod species composition and distribution (Clarke 1980; Cherel and Duhamel 2004; Cherel et al. 2004). Among the Antarctic penguins the deeper diving king and emperor penguins are thought to consume significant quantities of cephalopods (Williams 1995). Antarctic top predators such as emperor penguins catch larger specimens and a greater diversity of squid than fishing trawls during research cruises (Rodhouse 1990). The share of squid in the emperor penguin diet, however, is subject to substantial geographical variation, ranging from $3 \%$ at Pointe Géologie to 69\% (wet mass) at Taylor glacier colony (Offredo and Ridoux 1986; Klages 1989; Gales et al. 1990; Robertson et al. 1994; Pütz 1995; Cherel and Kooyman 1998) and $74 \%$ in diet samples collected in the Weddell Sea (Ainley et al. 1992). Comprising about 3,000 breeding pairs, the emperor penguin colony of Pointe Géologie is average sized among the 46 documented colonies (Woehler 1993; Mellick and Bremers 1995; Messick et al. 1999; Coria and Montalti 2000; Todd et al. 2004). So far, feeding and alimentation of emperor penguins were studied once in this colony some 20 years ago (Offredo et al. 1985), a good reason to conduct our dietary study at this breeding site. 


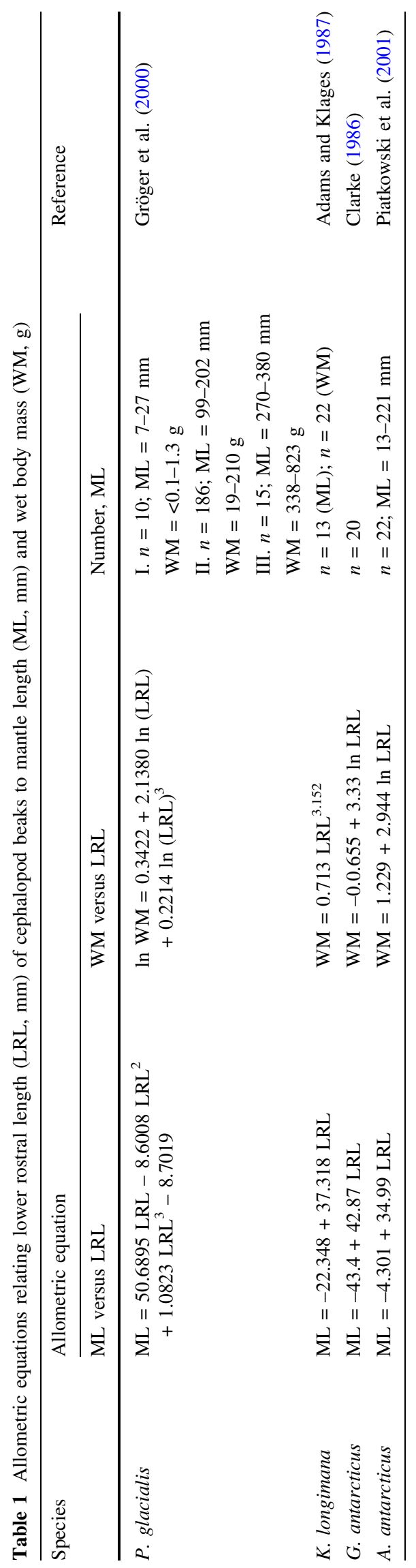

Here, we use cephalopod beaks collected from stomach samples of dead emperor penguin chicks at the Pointe Géologie colony (a) to analyse species inventory, size and body mass distribution of the emperor penguin's cephalopod prey, (b) to reconstruct cephalopod trophic ranges in the Dumont d'Urville Sea food web, and (c) to estimate the trophic impact of the emperor penguin on the cephalopod community.

\section{Materials and methods}

Field sampling

Field work was conducted at the Pointe Géologie emperor penguin colony $\left(66^{\circ} 40^{\prime} \mathrm{S}, 140^{\circ} 01^{\prime} \mathrm{E}\right)$, near Dumont d'Urville (DDU) station in Adélie Land, between November 3rd and December 16th 2004, and between September 25th and November 11th 2005. About 3,000 pairs of emperor penguins breed in this colony. Its size has remained constant since the early 1980s (Barbraud and Weimerskirch 2001). At this stage of the chick-rearing period, when chicks are 2-4 months old, the most intensive feeding occurs (Mougin 1966; Isenmann 1971). The colony was monitored regularly for chick carcasses and entire stomachs $(n=20$ in 2004; $n=12$ in 2005) were collected by dissection within $24 \mathrm{~h}$ after demise. Sampled stomachs were kept frozen until further analysis.

Laboratory methods

Stomach contents were sieved through a mesh size of $200 \mu \mathrm{m}$ to collect all relevant dietary remains. Cephalopod beaks and fish otoliths were stored in $70 \%$ ethanol. We identified cephalopod species by comparing the lower beaks to a reference collection held at IFM-GEOMAR, Kiel and by reference to Clarke (1986). Lower rostral length (LRL) of the cephalopod beaks was measured with digital callipers $( \pm 0.1 \mathrm{~mm})$. Small beaks (LRL $<2 \mathrm{~mm}$ ) were measured by the stage micrometer installed in a stereo microscope. Dorsal mantle length (ML in millimetres) and wet body mass (in grams) were derived from LRL by means of published allometric relationships (Table 1).

Stable nitrogen and carbon isotope signatures $\left(\delta^{15} \mathrm{~N}\right.$, $\delta^{13} \mathrm{C}$ ) of body tissue provide important information on trophic relations within an ecosystem. $\delta^{13} \mathrm{C}$ is commonly used as a carbon source tracer (e.g. Lesage et al. 2001), because it increases by $\leq 1 \%$ from one trophic level to the next (e.g. Peterson and Fry 1987; Michener and Schell 1994). Thus it can provide information on the geographical origin of migrating organisms, too, whereas $\delta^{15} \mathrm{~N}$ is indicative of the trophic distance of an organism from the primary food source of the corresponding food chain (e.g. 
Rau et al. 1991, 1992; Jacob et al. 2006). Fractionation of $\delta^{15} \mathrm{~N}$ ranges between 1.4 and $3.3 \%$ per trophic level (Minagawa and Wada 1984; Post 2002; McCutchan et al. 2003). We determined stable isotope ratios (both $\delta^{15} \mathrm{~N}$ and $\delta^{13} \mathrm{C}$ ) in a sub-sample of 65 beaks from the sampling year 2004 ( $n=996$ beaks from 20 chicks). No beaks from 2005 were analysed, because of the smaller number of samples (12 chicks) and in order to avoid differential storage effects on isotope ratios. Squid beak sub-samples were selected to represent the available size ranges of the four cephalopod (squid) species (see results). In Psychroteuthis glacialis ten beaks were selected randomly from the density maximum (median $10 \%$ of beaks) of the two modes of the beak size distribution (Fig. 1a), in Kondakovia longimana ten beaks were selected randomly from the smallest $10 \%$, the largest $10 \%$ and the medium sized $10 \%$ of beaks and in Gonatus antarcticus and Alluroteuthis antarcticus all beaks measured ( $n=10$ and $n=5$ beaks, respectively) were analysed.
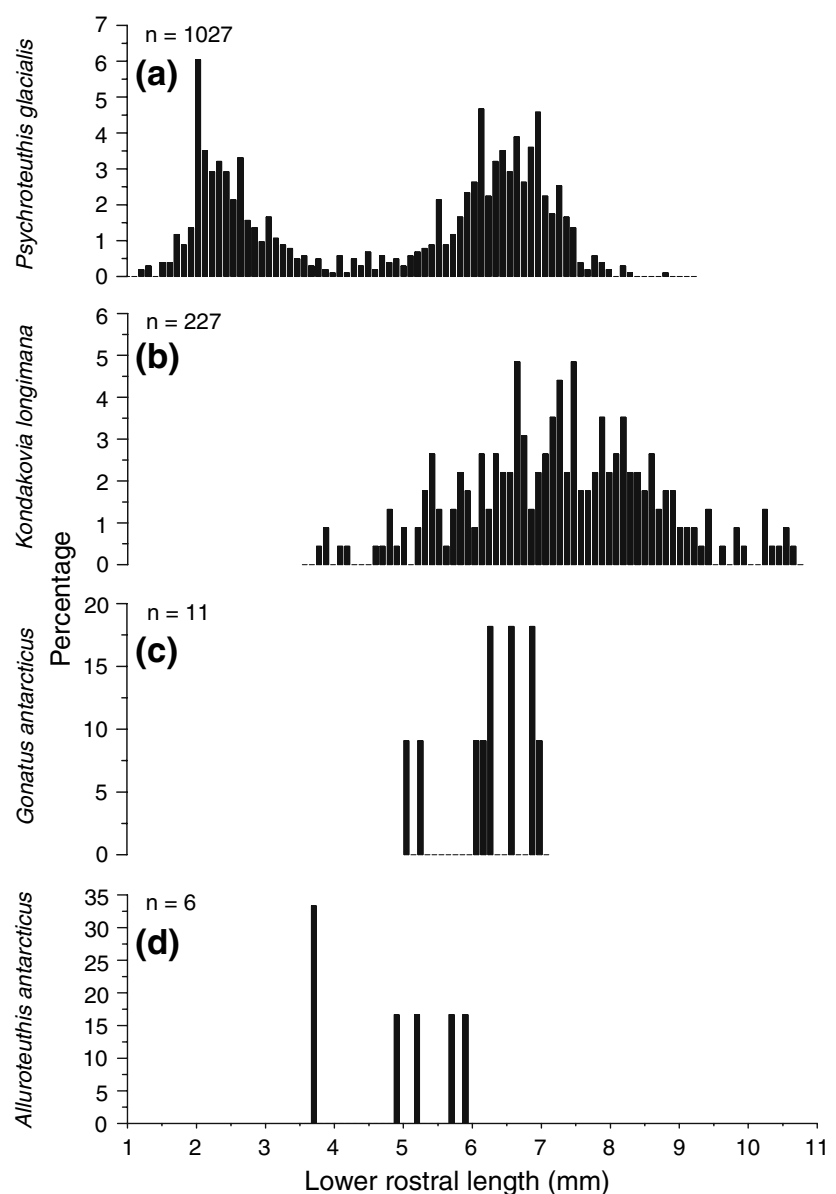

Fig. 1 Beak length-frequency distributions for a $P$. glacialis, b $K$. longimana, and c $G$. antarcticus and A. antarcticus based on stomach contents of 31 emperor penguin chick carcasses collected in $2004(N=20)$ and in $2005(N=11)$
Prior to isotope analysis, samples were dried and ground to a fine powder using a pebble mill. Stable isotope analysis and concentration measurements of nitrogen and carbon were performed simultaneously with a THERMO/ Finnigan MAT Delta plus isotope ratio mass spectrometer, coupled to a THERMO NA 2500 elemental analyzer via a THERMO/Finnigan Conflo II-interface (GeoBio-Center at Ludwig-Maximilans-Universität, München). Stable isotope ratios are given in the conventional delta notation $\left(\delta^{13} \mathrm{C}\right.$; $\delta^{15} \mathrm{~N}$ ) relative to atmospheric $\mathrm{N}_{2}$ (Mariotti 1984) and PDB (PeeDee Belemnite standard). Standard deviation for repeated measurements of lab peptone standard was $<0.15 \%$ for nitrogen and carbon. Standard deviations of concentration measurements of replicates of our lab standard are $<3 \%$ of the concentration analysed.

Trophic analysis

We used a full factorial analysis of covariance (ANCO$\mathrm{VA})$ to establish linear models of the stable isotope ratio $\left(\delta^{15} \mathrm{~N}, \delta^{13} \mathrm{C}\right)$ versus the squid species and the covariate LRL, after checking the data for normality and homogeneity of variances. In order to evaluate whether $\delta^{13} \mathrm{C}$ was affected by beak fat content, we included the $\mathrm{C} / \mathrm{N}$ ratio that represents a lipid content proxy (McConnaughey and McRoy 1979) in the ANCOVA of $\delta^{13} \mathrm{C}$ as a second covariate. The resulting $\delta^{15} \mathrm{~N}$ model was used to estimate the $\delta^{15} \mathrm{~N}$ value of each beak for the corresponding LRL collected from different species. Data were statistically analysed using the software JMP by Statistical Analysis System (SAS) Institute. Significance of the results was judged at level 0.05. Mean values are presented \pm 1 standard deviation.

We inferred trophic level distribution of the cephalopods from the $\delta^{15} \mathrm{~N}$ frequency distribution of the beaks and trophic impact of the emperor penguins on the cephalopod community from a cephalopod body mass weighted $\delta^{15} \mathrm{~N}$ frequency distribution.

Trophic level of emperor penguins at different breeding sites

In order to explore the relationship between diet composition (crustaceans, squid and fish as \% of prey mass) and trophic level of emperor penguins, we compared data from seven different colonies, Amanda Bay (Gales et al. 1990), Pointe Géologie (Offredo et al. 1985), Cape Roget and Coulman Island (Cherel and Kooyman 1998), Auster Glacier and Taylor Glacier (Robertson et al. 1994) and the Drescher Inlet (Klages 1989). Emperor penguin trophic level in each colony was calculated from diet composition and average trophic level of the three diet items by means of a mass weighted mean: 


$$
\begin{aligned}
\delta^{15} \mathrm{~N}_{\text {emperor }}= & 3.3+\left(\text { Mass } \%_{\text {crust }} \times \delta^{15} \mathrm{~N}_{\text {crust }}+\text { Mass } \%_{\text {squid }}\right. \\
& \left.\times \delta^{15} \mathrm{~N}_{\text {squid }}+\text { Mass } \%_{\text {fish }} \times \delta^{15} \mathrm{~N}_{\text {fish }}\right) / 100
\end{aligned}
$$

where $\delta^{15} \mathrm{~N}_{\text {crust }}=3.5$ (U. Jacob, unpublished data), $\delta^{15} \mathrm{~N}_{\text {fish }}=9.04 \quad$ (U. Jacob, unpublished data) and $\delta^{15} \mathrm{~N}_{\text {squid }}=5.93$ (this study, mass weighted mean) and 3.3 is the average tropic level step size (Minagawa and Wada 1984).

\section{Results}

Cephalopod prey composition

Stomach content was sampled from 32 emperor penguin chicks at Pointe Géologie and contained fish and crustacean remains, cephalopod beaks and pebbles. Fish eye lenses of up to several hundreds per sample indicated that fish had an important share in the penguin diet. Few otoliths were found, all coming from Nototheniidae. Lower cephalopod beaks occurred in 31 of 32 stomach samples with a total number of 1,327 (996 in 2004 and 331 in 2005). The average number of beaks per chick stomach content was $41 \pm 51$ and did not differ significantly between 2004 and $2005(P=0.193$, ANOVA of $\log 10$ transformed data). A total of 1,317 lower beaks could be allocated to species. These beaks were still uneroded or at least did not show severe signs of digestion, i.e. the rostrum was still sharp albeit with partly broken and abraded wings. We identified four cephalopod (squid) species, $P$. glacialis (Psychroteuthidae; $N_{2004}=736, N_{2005}=322$ ), K. longimana (Onychoteuthidae; $N_{2004}=227, N_{2005}=5$ ), G. antarcticus (Gonatidae; $N_{2004}=10, \quad N_{2005}=1$ ), and A. antarcticus (Neoteuthidae; $N_{2004}=16, N_{2005}=0$ ).

A total of 1,271 lower beaks were in sufficiently good condition to allow for measurement of lower rostrum length (LRL, Fig. 1). P. glacialis showed a distinct bimodal distribution of LRL, with one peak at $2-3 \mathrm{~mm}$ and a second one at 6-7 $\mathrm{mm}$ in both years. The LRL distribution of $K$. longimana was unimodal $(7.09 \pm 1.36 \mathrm{~mm})$. The few beaks in $G$. antarcticus $(6.20 \pm 0.62 \mathrm{~mm})$, and A. antarcticus $(4.85 \pm 0.96 \mathrm{~mm})$ provided no clues on size distribution.

The corresponding mantle length ML amounted to $76 \mathrm{~mm}$ (left peak) and $251 \mathrm{~mm}$ (right peak) in P. glacialis, to a mean of $242 \pm 51 \mathrm{~mm}$ in $K$. longimana, and to a mean of $222 \pm 27$ and $165 \pm 34 \mathrm{~mm}$ in $G$. antarcticus and A. antarcticus, respectively. The corresponding wet body mass WM amounted to $10 \mathrm{~g}$ (left peak) and $322 \mathrm{~g}$ (right peak) in P. glacialis, to a mean of $384 \pm 224 \mathrm{~g}$ in K. longimana, and to a mean of $233 \pm 70$ and $390 \pm 201 \mathrm{~g}$ in G. antarcticus and A. antarcticus, respectively. The pooled frequency distribution of both mantle length and wet body mass were distinctly bimodal (Fig. 2).

Trophic levels and trophic relations

Nitrogen stable isotope ratio of the four examined squid species was significantly affected by squid species and beak size, as indicated by the multiple linear model (Fig. 3a):

$$
\begin{aligned}
\delta^{15} \mathrm{~N}= & 4.5569+0.1298 \times \mathrm{LRL}+1.5238 \times \text { TaxonN } \\
& +0.3521(\mathrm{LRL}-6.2800) \times \text { TaxonN }
\end{aligned}
$$

where TaxonN $=1$ for $P$. glacialis, $G$. antarcticus, $A$. antarcticus, and -1 for $K$. longimana.

$\delta^{15} \mathrm{~N}$ values were indistinguishable in $P$. glacialis (range $4.68-8.02 \%$, mean $=6.60 \pm 1.06 \%$ o $), \quad$ G. antarcticus (range $5.52-8.05 \%$, mean $=6.88 \pm 0.74 \%$ ) and $A$. antarcticus (range $4.25-6.68 \%$, mean $=5.55 \pm 0.91 \%$ ), but significantly lower in $K$. longimana (range $2.39-5.67 \%$, mean $=3.67 \pm 0.88 \%$ o . Moreover, $\delta^{15} \mathrm{~N}$ decreased in $K$. longimana by about $1.2 \%$ from small to large beaks (Fig. 3a).

Carbon stable isotope ratio of the four examined squid species was significantly affected by squid species and
Fig. 2 a Size class (mm ML) and $\mathbf{b}$ body mass (g WM) of all four squid species combined $(n=1,271)$. ML and WM were calculated from beak length LRL by means of the allometric relations in Table 1
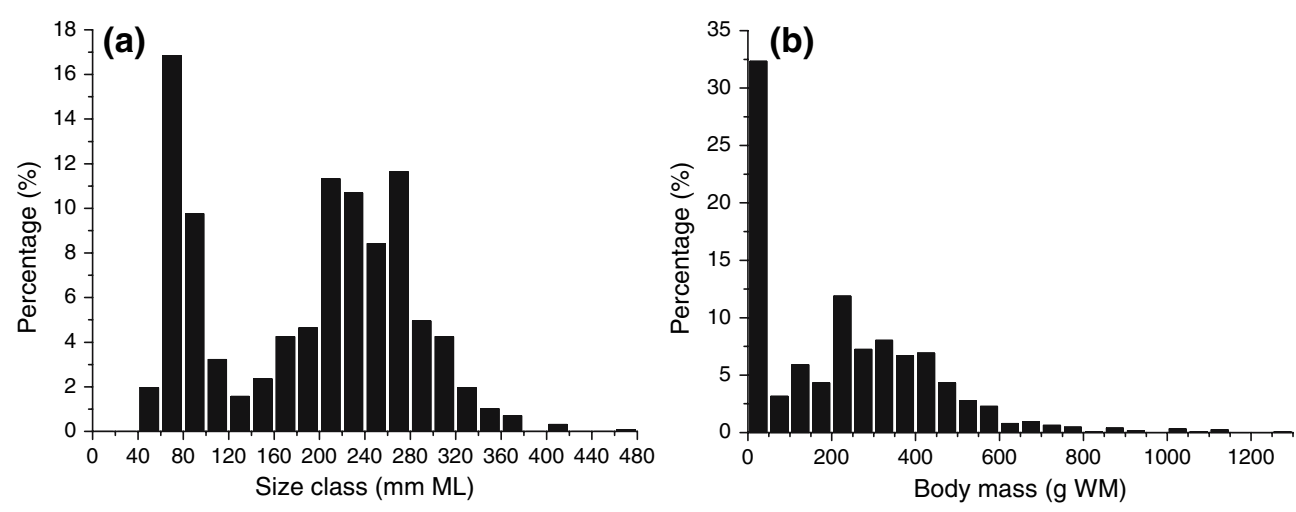


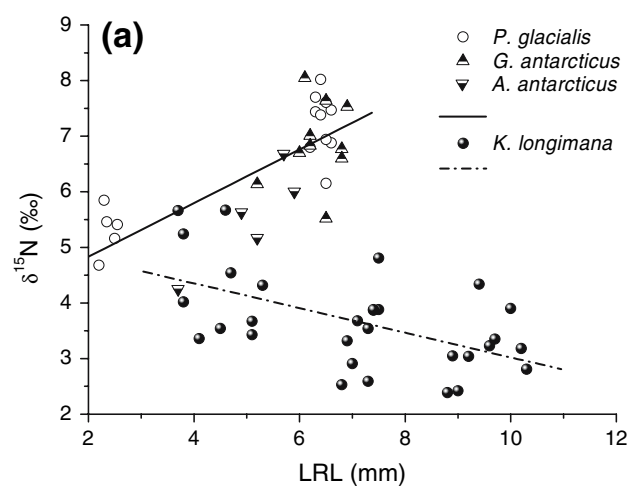

Fig. 3 Multiple linear models of stable isotope ratios versus lower rostral length of squid beaks $(L R L)$ and squid taxon. Models were established by full factorial ANCOVA. a $\delta^{15} \mathrm{~N}=4.5569+0.1298 \times$ LRL $+1.5238 \times$ TaxonN $+0.3521(\mathrm{LRL}-6.2800) \times$ Taxon $N \quad N=$ $60, R^{2}=0.821, P<0.001$. TaxonN $=1$ for $P$. glacialis, . antarcticus,

beak size, too (Fig. 3b), but not by beak $\mathrm{C} / \mathrm{N}$ ratio $(P=0.493)$ :

$$
\begin{aligned}
\delta^{13} \mathrm{C}= & -26.9739+0.5756 \times \mathrm{LRL}+1.1099 \times \text { TaxonC } \\
& +0.3796(\mathrm{LRL}-6.2800) \times \text { TaxonC }
\end{aligned}
$$

where TaxonC $=1$ for G. antarcticus, A. antarcticus, and -1 for P. glacialis, K. longimana.

$\delta^{13} \mathrm{C}$ values fell in two significantly different groups, $P$. glacialis (range -25.81 to $-23.73 \%$, mean $=-24.67 \pm$ $0.70 \%$ ) and $K$. longimana (range -25.63 to $-22.95 \%$, mean $=-24.33 \pm 0.78 \%$ o ) on the one hand, and G. antarcticus (range -24.44 to $-20.72 \%$, mean $=-22.01 \pm$ $1.02 \%$ ) and $A$. antarcticus (range -25.45 to $-21.92 \%$, mean $=-23.80 \pm 1.59 \%$ ) on the other hand.

In terms of $\delta^{15} \mathrm{~N}$, the trophic spectrum of the four squid species combined covered a range from 2.5 to $8 \%$ (Fig. 4a). This spectrum exhibited three peaks at approximately $3.5,4.75-5$ and $6.75-7 \%$. Emperor penguins concentrated their feeding on the upper trophic range of their

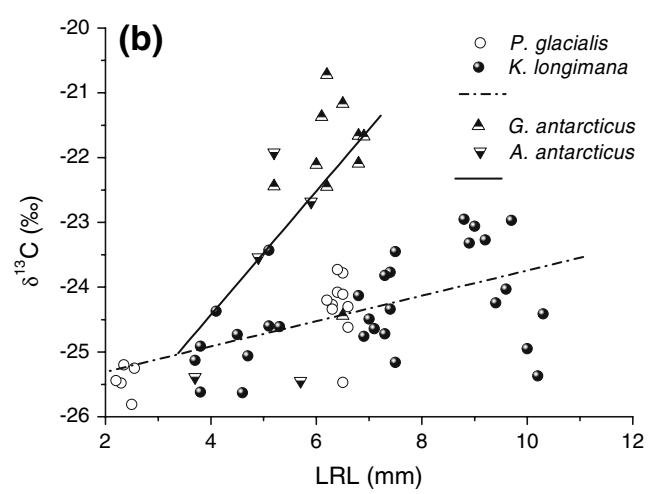

A. antarcticus, and -1 for $K$. longimana. b $\delta^{13} \mathrm{C}=-26.9739+$ $0.5756 \times$ LRL $+1.1099 \times$ TaxonC $+0.3796($ LRL -6.2800$) \times$ TaxonC $N=60, R^{2}=0.580, P<0.001$. TaxonC $=1$ for $G$. antarcticus, A. antarcticus, and -1 for $P$. glacialis, $K$. longimana

cephalopod prey. Squids with $\delta^{15} \mathrm{~N}$ above $6 \%$ contributed more than $68 \%$ to the squid body mass consumed by the penguins.

Trophic level of emperor penguins at different breeding sites

Emperor penguins trophic level clearly depends on its diet composition, as indicated by the ternary plot in Fig. 5 . Trophic level was highest where the penguin diet was rich in fish such as in Amanda Bay $(96.8 \%$ fish, $\delta^{15} \mathrm{~N}=12.23 \%$ ), Pointe Géologie (95.0\% fish, $12.14 \%$ ), Cape Roget $(93.0 \%$ fish, $12.12 \%$ ) and Coulman Island $(88.0 \%$ fish, $11.97 \%)$. When squid was dominant or of similar significance as fish, trophic position of penguins was distinctly lower, i.e. at Auster Glacier (44.7\% squid, $\delta^{15} \mathrm{~N}=10.95 \%$ ) and Taylor Glacier (69.3\% squid, $10.18 \%$ o . Emperor penguin trophic level was lowest when krill dominated the diet as in Drescher Inlet $(52.1 \%$ krill, $\delta^{15} \mathrm{~N}=9.15 \%$, Fig. 5).
Fig. $4 \delta^{15} \mathrm{~N}$ frequency distribution of a beak numbers and $\mathbf{b}$ squid body mass. $\delta^{15} \mathrm{~N}$ of each beak $(n=1,271)$ was estimated by the multiple linear model of $\delta^{15} \mathrm{~N}$ versus beak length and species (Fig. 3), and squid body mass was estimated from beak length by the species specific allometric relations (Table 1)
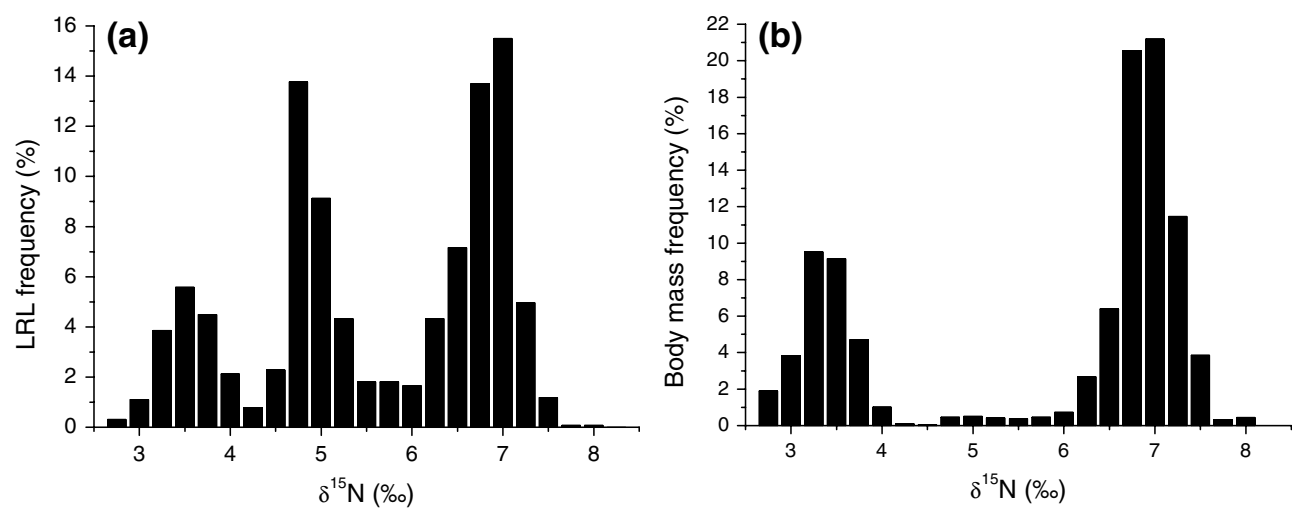


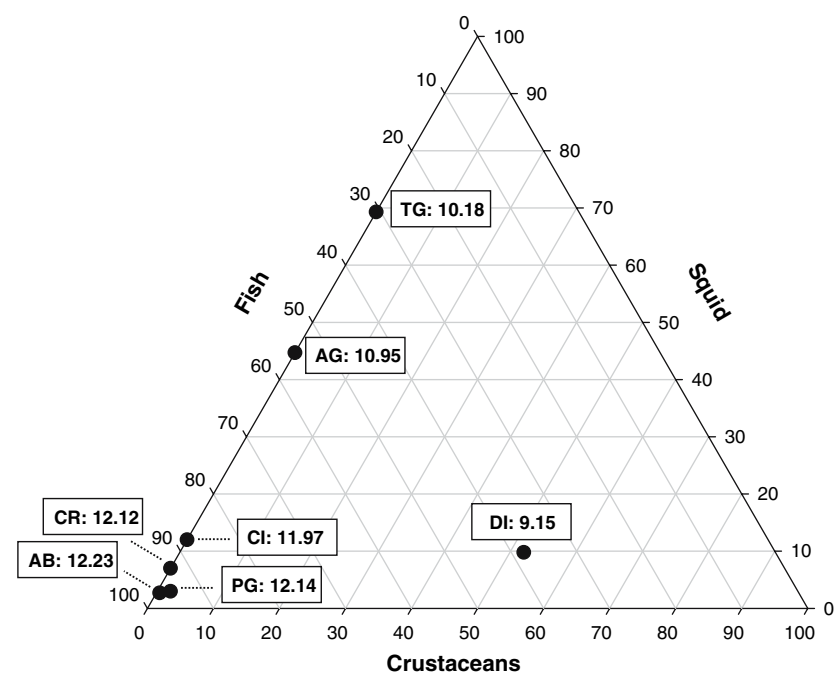

Fig. 5 Ternary plot showing diet composition (\% mass) and corresponding calculated trophic level of emperor penguins at different breeding sites: Amanda Bay $(A B)$, Pointe Géologie $(P G)$, Cape Roget $(C R)$, Coulman Island $(C I)$, Auster Glacier $(A G)$, Taylor Glacier $(T G)$, Drescher Inlet $(D I)$. Numbers in rectangles are emperor penguin $\delta^{15} \mathrm{~N}$ values estimated from diet composition and average trophic level of the three diet items fish, squid and crustaceans by means of a mass weighted mean (see "Materials and methods")

\section{Discussion}

Significance of squid in penguin alimentation at Pointe Géologie

Inferring diet composition from chick stomach contents has some disadvantages. We do not know whether the chick stomach content is a true reflection of adult feeding, because regurgitation may involve a bias related to prey item size or taxon, and digestion rate may differ between prey items, as observed by Wilson et al. (1985). Furthermore, the chick stomach content is in an advanced digestion state, making a quantitative weight based analysis difficult. These problems, however, do not seriously affect our analysis, because we do not aim at feeding rates, but on the composition of one particular prey group, squid. These are represented by their beaks which are more resistant to digestion than other hard part items such as fish otoliths in penguin diet (Pütz 1995) and thus reflect squid prey composition over a longer period of time.

The four cephalopod species identified in our chick stomach samples ( $P$. glacialis, $K$. lonigimana, A. antarcticum, $G$. antarcticum) constitute the major squid prey of breeding emperor penguins all around the Antarctic (Offredo and Ridoux 1986; Piatkowski and Pütz 1994; Robertson et al. 1994; Cherel and Kooyman 1998). The share of each species differs from colony to colony, $P$. glacialis usually being the most frequent one (Collins and Rodhouse 2006). Other species, e.g. Galiteuthis glacialis, Moroteuthis ingens, Mesonychoteuthis hamiltoni or Histoteuthis sp. play a minor role in the emperor penguin diet (Offredo et al. 1985; Piatkowski and Pütz 1994; Robertson et al. 1994; but see also Ainley et al. 1992).

It remains uncertain whether the emperor penguins exploit the full size range of squid present off Adélie Land during the breeding season because independent information on squid size (ML) range in this region is lacking (but see below). Nevertheless, the population of the most abundant prey species, $P$. glacialis, is assumed to consist of a juvenile and an adult cohort (Offredo et al. 1985), which appears to be fully represented by the bimodal beak sizefrequency distribution (Fig. 2). This may be different in the larger $K$. longimana, of which specimens up to $16.4 \mathrm{~mm}$ LRL (588 $\mathrm{mm}$ ML) have been reported from Crozet Island waters (Cherel et al. 2004).

Offredo and Ridoux (1986) reported a 3\% (wet mass) share of squid in the diet of emperor penguins at Pointe Géologie which is quite low compared to other colonies (up to 69\%, Robertson et al. 1994). Our findings of up to several hundred fish eye lenses in each chick stomach indicate that indeed finfish is of particular significance in the penguin diet at Pointe Géologie. Nototheniidae predominate, according to the otoliths found, as reported in earlier studies from this area (Offredo and Ridoux 1986). We presume that the Antarctic Silverfish Pleuragramma antarcticum is the major fish prey, as reported from other colonies (e.g. Offredo and Ridoux 1986; Klages 1989; Gales et al. 1990; Cherel and Kooyman 1998).

Trophic position and range of squid in the Dumont d'Urville Sea

P. glacialis $\left(\delta^{15} \mathrm{~N} 6.60 \pm 1.06 \%\right)$, G. antarcticus $\left(\delta^{15} \mathrm{~N}\right.$ $6.88 \pm 0.74 \%$ oo $)$ and $A$. antarcticus $\left(\delta^{15} \mathrm{~N} 5.55 \pm 0.91 \%\right.$, are positioned about one trophic level higher (assuming a $3 \%$ increase from one trophic level to the next) than $K$. longimana $\left(\delta^{15} \mathrm{~N} 3.67 \pm 0.88 \%\right.$ oo $)$ The increase of $\delta^{15} \mathrm{~N}$ in the former three species with beak size (about $2 \%$ from 2 to $7 \mathrm{~mm}$ LRL, Fig. 3a) indicates an ontogenetic shift in diet towards prey of higher trophic level, as observed in many marine predatory species (Cherel and Duhamel 2003; Phillips et al. 2003; Schmidt et al. 2003). Small and/or juvenile squid have been found to consume mostly crustaceans; they switch to a fish- and cephalopod-based diet as they grow larger (Breiby and Jobling 1985; Lipinski 1987; Ivanovic and Brunetti 1994; Pierce et al. 1994; Collins and Pierce 1996; Coelho et al. 1997; Quetglas et al. 1999). These changes in diet have been related to the energetic advantages of a fish diet compared to a crustacean diet (Pierce et al. 1994), in addition to the simple principle that a wider size-range 
of prey is available to larger squid (Rodhouse and Nigmatullin 1996).

Small individuals of $P$. glacialis have a trophic level slightly above euphausiids (about $3-5 \%$, U. Jacob et al., unpublished data), and large ones below pelagic fish $(\geq 9 \%$, U. Jacob et al., unpublished data). In K. longimana, however, $\delta^{15} \mathrm{~N}$ decreases with beak size, contradictory to common wisdom as well as to observations in this species at Crozet Island (Cherel and Hobson 2005). We can only speculate how this isotope pattern and the overall low trophic level (Cherel and Hobson 2005 report a similar $\delta^{15} \mathrm{~N}$ range) of $K$. longimana may be explained. $K$. longimana is described as a pelagic predator (Lubimova 1985; Collins and Rodhouse 2006) feeding on zooplankton and micronekton (Nemoto et al. 1985), with a strong preference for krill (Nemoto et al. 1985, 1988; Lu and Williams 1994). Both large pelagic crustaceans and fish have similar or even higher trophic levels than $K$. longimana (U. Jacob et al., unpublished data), only small pelagics such as copepods and pteropods would fit into the picture. Seasonal variability of krill $\delta^{15} \mathrm{~N}$ may play a role too. Frazer (1996) reported $\delta^{15} \mathrm{~N}$ values ranging from -2 to $+5 \% \delta^{15} \mathrm{~N}$, mainly dependent on changes in the isotopic composition of algal food resources exploited by krill offshore along the west coast of the Antarctic Peninsula and in the Weddell Sea. Lacking further detailed information on the feeding habits of $K$. longimana, trophic relations of this species remain enigmatic.

The four cephalopod species taken as a whole cover a trophic range from 2.5 to $8 \%{ }_{0} \delta^{15} \mathrm{~N}$, corresponding to about two trophic levels (Fig. 4a). The lower end of the range is occupied by large $K$. longimana (see above), whereas large $P$. glacialis are positioned at the upper end. This is in accordance with their reported diet of mainly euphausiids, Nototheniidae and P. antarcticum (Kear 1992; Lu and Williams 1994; Collins et al. 2004).

We found a significant increase in $\delta^{13} \mathrm{C}$ with beak size in all four species (Fig. 3b). This relation, however, should be taken with a grain of salt regarding A. antarcticus and G. antarcticus, because of the few values and small range of beak length data (Fig. 2). Thus, two sound findings have to be discussed, the significant higher $\delta^{13} \mathrm{C}$ in $A$. antarcticus and $G$. antarcticus compared to $P$. glacialis and $K$. longimana, and the significant increase of $\delta^{13} \mathrm{C}$ with beak size in the latter two species. In the Southern Ocean bulk phytoplankton $\delta^{13} \mathrm{C}$ varies geographically by about 10\% (Goericke and Fry 1994), and these differences should be traceable through the food web. Accordingly, the higher $\delta^{13} \mathrm{C}$ values in A. antarcticus and $G$. antarcticus point towards migration from a remote location supplying a different plankton food base, either seasonal or ontogenetic, of these reportedly Antarctic and sub Antarctic (Collins and Rodhouse 2006) species. The comparatively lower $\delta^{13} \mathrm{C}$ in small (young) $P$. glacialis and $K$. longimana indicate that these animals grew up in high-Antarctic waters. The increase of $\delta^{13} \mathrm{C}$ with beak size, however, may be related to an ontogenetic shift in the diet-already indicated by the size related change in $\delta^{15} \mathrm{~N}$-either to prey that undergoes seasonal migration, maybe coupled to the seasonal pattern in sea ice cover, or related to age dependent seasonal migration patterns (between pelagic, slope and shelf waters).

Trophic impact of the emperor penguin on the squid community

Provided that our beak samples are representative for the emperor penguin's squid catch in the Dumont d'Urville Sea, than the penguins prey on squids between 40 and $480 \mathrm{~mm}$ ML (Fig. 2a), i.e. between 2 and 1,272 g wet body mass (Fig. 2b). Several Antarctic cephalopod species, however, can grow distinctly larger, e.g. K. longimana, A. antarcticus and $M$. hamiltoni. Specimens up to $1,000 \mathrm{~mm}$ ML have been reported from stomach contents of Patagonian toothfish (Xavier et al. 2002), of southern bottlenose whales and sperm whales (Clarke 1980; Slip et al. 1995), of southern elephant seal (e.g. Piatkowski et al. 2002), and of wandering albatrosses who occasionally encounter surface drifting squid who lost neutral buoyancy (Lipinski and Jackson 1989). From the positive correlation of diving depth (up to $564 \mathrm{~m}$ in penguins, up to $2,000 \mathrm{~m}$ in toothfish, whales and elephant seals) and squid size, Collins and Rodhouse (2006) conclude that larger squid live deeper and thus cannot be reached by emperor penguins. This, however, remains an open question because it may well be that there is a size limit to the prey handling capacity of emperor penguins.

The cephalopod prey of the emperor penguin covers a wide trophic range $\left(2.5-8.0 \% \delta^{15} \mathrm{~N}\right.$, Fig. $4 \mathrm{a}$, mean mass weighted $\delta^{15} \mathrm{~N}=5.9 \%$, Fig. $4 \mathrm{~b}$ ), but their predatory impact concentrates on the upper part of this range $\left(68 \%>6 \% \delta^{15} \mathrm{~N}\right.$, Fig. $\left.4 \mathrm{~b}\right)$. This is a consequence of squid species specific size range (Fig. 1) and size-trophic level relationship (Fig. 3). Assuming that average values for the trophic level of euphausiids $\left(3.5 \% \delta^{15} \mathrm{~N}\right.$, U. Jacob, unpublished data), P. antarcticum $\left(9.0 \% \delta^{15} \mathrm{~N}\right.$, U. Jacob, unpublished data) and squid $\left(5.9 \% \delta^{15} \mathrm{~N}\right.$, this study) are valid for the whole Antarctic, we can infer the trophic position of emperor penguins at different sites from diet composition (Fig. 5). Trophic level is high when diet is rich in fish, and low when diet is rich in krill, and intermediate when squid plays a major role. Overall the trophic level of the emperor penguin can vary by $2 \% \delta^{15} \mathrm{~N}$ between colonies, rather a full trophic step $( \pm 3.3 \%$ o for protein rich diet, Wada et al. 1987; McCutchan et al. 2003). So far, $\delta^{15} \mathrm{~N}$ has been determined in emperor penguins 
from the Weddell Sea only (U. Jacob, unpublished data), and this value, $10.28 \%$, is slightly above our calculated value of $9.15 \%$. Indeed this higher $\delta^{15} \mathrm{~N}$ value would be consistent with high proportions of fish and squid in stomach samples of emperor penguins collected in the marginal ice zone of the Weddell Sea (Ainley et al. 1992). It remains to be seen whether direct measurement in other colonies confirm our findings. If so, then the flexibility in alimentation of the emperor penguin translates in distinct variability of its position in the trophic hierarchy, a feature that should be kept in mind when comparing food webs of different Antarctic regions.

\section{Conclusions}

Emperor chick stomach contents yield valuable ecological information far beyond just the penguin's diet. The combined taxonomic, morphometric and trophic (by means of stable isotope ratios) analysis of cephalopod beaks from chick stomachs provides otherwise inaccessible data on squid trophic ecology, including indications of migration patterns and ontogenetic shifts in diet. Moreover, it enables us to infer (qualitatively) the trophic impact of a particular emperor penguin colony on the squid community in its feeding area. Our approach might be developed further along a number of different lines: (a) it may be used to compare squid trophic ecology as well as penguin trophic impact between different regions/colonies; (b) coupling with models of penguin metabolism it will allow to estimate quantitative trophic impact on the squid community (i.e. consumption); and (c) one might explore whether fish otoliths can be used in a similar way. Finally, collecting of dead chicks and preservation of their stomach contents could form the base of a regular monitoring programme in easily accessible colonies, in order to track long-term changes in penguin as well as squid trophic ecology which may be indicative of climate change induced modifications of the Antarctic food web.

Acknowledgments We are very grateful to A. Ancel, C. Gilbert and M. Beaulieu, DEPE/CNRS Strasbourg, France, for collaboration and their help in the field and laboratory work. Logistical and financial support was provided by the Institut Polaire Français (IPEV) and Terre Australes et Antarctiques Françaises (TAAF). We like to acknowledge C. Mayr from the GeoBio-Center at the LudwigMaximilians-Universität München, Germany, for measuring the stable isotope samples.

\section{References}

Adams NJ, Klages NT (1987) Seasonal variation in the diet of the king penguin (Aptenodytes patagonicus) at sub-Antarctic Marion Island. J Zool Lond 212:303-324
Ainley DG, Ribic CA, Frazer WR (1992) Does prey preference affect habitat choice in Antarctic seabirds? Mar Ecol Prog Ser 90:207221

Barbraud C, Weimerskirch H (2001) Emperor penguins and climate change. Nature 411:183-186

Breiby A, Jobling M (1985) Predatory role of the flying squid (Todarodes sagittatus) in north Norwegian waters. NAFO Sci Counc Stud 9:125-132

Cherel Y, Duhamel G (2003) Diet of the squid Moroteuthis ingens (Teuthoidea: Onychoteuthidae) in the upper slope waters of the Kerguelen Islands. Mar Ecol Prog Ser 250:197-203

Cherel Y, Duhamel G (2004) Antarctic jaws: cephalopod prey of sharks in Kerguelen waters. Deep Sea Res I 51:17-31

Cherel Y, Hobson KA (2005) Stable isotopes, beaks and predators: a new tool to study the trophic ecology of cephalopods, including giant and colossal squids. Proc R Soc B 272:1601-1607

Cherel Y, Kooyman GL (1998) Food of emperor penguins (Aptenodytes forsteri) in the western Ross Sea, Antarctica. Mar Biol 130:335-344

Cherel Y, Duhamel G, Gasco N (2004) Cephalopod fauna of subantarctic islands: new information from predators. Mar Ecol Prog Ser 266:143-156

Clarke MR (1980) Cephalopoda in the diet of sperm whales of the Southern Hemisphere and their bearing on sperm whale biology. Discov Rep 37:1-324

Clarke MR (1986) A handbook for the identification of cephalopod beaks. Clarendon Press, Oxford

Coelho M, Domingues P, Balguerias E, Fernandez M, Andrade JP (1997) A comparative study of the diet of Loligo vulgaris (Lamarck, 1799) (Mollusca: Cephalopoda) from the south coast of Portugal and the Saharan Bank (Central-East Atlantic). Fish Res 29:245-255

Collins MA, Pierce GJ (1996) Size selectivity in the diet of Loligo forbesi (Cephalopoda: Loliginidae). J Mar Biol Assoc UK 76:1081-1090

Collins MA, Rodhouse PGK (2006) Southern ocean cephalopods. Adv Mar Biol 50:191-265

Collins MA, Allcock AL, Belchier M (2004) Cephalopods of the South Georgia slope. J Mar Biol Assoc UK 84:415-419

Coria NR, Montalti D (2000) A newly discovered breeding colony of emperor penguins Aptenodytes forsteri. Mar Ornithol 28:119120

Frazer TK (1996) Stable isotope composition $\left(\delta^{13} \mathrm{C}\right.$ and $\left.\delta^{15} \mathrm{~N}\right)$ of larval krill, Euphausia superba, and two of its potential food sources in winter. J Plankton Res 18(8):1413-1426

Gales NJ, Klages NTW, Williams R, Woehler EJ (1990) The diet of the emperor penguin, Aptenodytes forsteri, in Amanda Bay, Princess Elizabeth Land, Antarctica. Antarct Sci 2:23-28

Goericke R, Fry B (1994) Variations of marine plankton $\delta^{13} \mathrm{C}$ with latitude, temperature, and dissolved $\mathrm{CO}_{2}$ in the world ocean. Global Biogeochem Cycles 8(1):85-90

Gröger J, Piatkowski U, Heinemann H (2000) Beak length analysis of the Southern Ocean squid Psychroteuthis glacialis (Cephalopoda: Psychroteuthidae) and its use for size and biomass estimation. Polar Biol 23:70-74

Isenmann P (1971) Contribution à l'éthologie et à l'écologie du manchot empereur à la colonie de Pointe Géologie. Oiseau Rev Fr Ornithol 41:9-64

Ivanovic M, Brunetti NE (1994) Food and feeding of Illex argentinus. Antarct Sci 6:185-193

Jacob U, Brey T, Fetzer I, Kaehler S, Mintenbeck K, Dunton K, Beyer K, Struck U, Arntz WE (2006) Towards the trophic structure of the Bouvet Island marine ecosystem. Polar Biol 29:106-113

Kear AJ (1992) The diet of Antarctic squid: a comparison of conventional and serological gut contents analyses. J Exp Biol Ecol 156:161-178 
Klages NTW (1989) Food and feeding ecology of emperor penguins in the eastern Weddell Sea. Polar Biol 9:385-390

Lesage V, Hammill MO, Kovacs KM (2001) Marine mammals and the community structure of the Estuary and Gulf of St. Lawrence, Canada: evidence from stable isotope analysis. Mar Ecol Prog Ser 210:203-221

Lipinski MR (1987) Food and feeding of Loligo vulgaris reynaudii from St Francis Bay, South Africa. S Afr J Mar Sci 5:557-564

Lipinski M, Jackson S (1989) Surface-feeding on cephalopods by procellariform seabirds in the southern Benguela region, South Africa. J Zool 218:549-563

Lu CC, Williams R (1994) Contribution of the biology of squid in the Prydz Bay region, Antarctica. Antarct Sci 62:223-229

Lubimova TG (1985) Results of Soviet investigation of the distribution and ecology of pelagic squids (Oegopsida) in the Southern Ocean. Sel Pap SC-CCAMLR 1985:79-111

Mariotti A (1984) Atmospheric nitrogen is a reliable standard for natural ${ }^{15} \mathrm{~N}$ abundance measurements. Nature 303:685-687

McConnaughey T, McRoy CP (1979) Food-web structure and the fractionation of carbon isotopes in the Bering Sea. Mar Biol $53: 257-262$

McCutchan JH Jr, William ML Jr, Kendall C, McGrath CC (2003) Variation in trophic shift for stable isotope ratios of carbon, nitrogen, and sulfur. Oikos 102:378-390

Mellick D, Bremers W (1995) A recently discovered breeding colony of emperor penguins (Aptenodytes forsteri) on the Budd Coast, Wilkes Land, East Antarctica. Polar Rec 31:426-427

Messick M, Splettstoesser JF, Harrison P, Gavrilo M (1999) New breeding site for emperor penguins (Aptenodytes forsteri) on Princess Martha Coast, Queen Maud Land, East Antarctica. Polar Rec 35:156-157

Michener RH, Schell DM (1994) Stable isotope ratios as tracers in marine aquatic food webs. In: Lajtha $\mathrm{K}$, Michener RH (eds) Stable isotopes in ecology and environmental science. Blackwell Scientific, Oxford, pp 138-158

Minagawa M, Wada E (1984) Stepwise enrichment of ${ }^{15} \mathrm{~N}$ along food chains, further evidence and the relation between $\delta^{15} \mathrm{~N}$ and animal age. Geochim Cosmochim Acta 48:1135-1140

Mougin J-L (1966) Observations écologiques à la colonie de manchots empereurs de Pointe Gélologie (Terre Adélie) en 1964. Oiseau Rev Fr Ornithol 36(3-4):166-226

Nemoto T, Okiyama M, Takahashi M (1985) Aspects of the roles of squid in food chains of marine Antarctic ecosystems. In: Siegfried WR, Condy PR, Laws RM (eds) Antarctic nutrient cycles and food webs. Springer, Berlin, pp 415-420

Nemoto T, Okiyama M, Iwasaki N, Kikuchi N (1988) Squid as predators of krill (Euphausia superba) and prey for sperm whales in the Southern Ocean. In: Sarhage D (ed) Antarctic Ocean and resource variability. Springer, Berlin, pp 292-296

Offredo C, Ridoux V (1986) The diet of emperor penguins Aptenodytes forsteri in Adélie Land, Antarctica. Ibis 128:409-413

Offredo C, Ridoux V, Clarke MR (1985) Cephalopods in the diets of emperor and Adélie penguins in Adélie Land, Antarctica. Mar Biol 86:199-202

Peterson BJ, Fry B (1987) Stable isotopes in ecosystem studies. Annu Rev Ecol Syst 18:293-320

Phillips KL, Nichols PD, Jackson GD (2003) Size-related dietary changes observed in the squid Moroteuthis ingens at the Falkland islands: stomach contents and fatty analyses. Polar Biol 26(7):474-485

Piatkowski U, Pütz K (1994) Squid diet of emperor penguins (Aptenodytes forsteri) in the eastern Weddell Sea, Antarctica during late summer. Antarct Sci 6:241-247
Piatkowski U, Pütz K, Heinemann H (2001) Cephalopod prey of king penguins (Aptenodytes patagonicus) breeding at Volunteer Beach, Falkland Islands, during austral winter 1996. Fish Res 52:79-90

Piatkowski U, Vergani DF, Stranganelli ZB (2002) Changes in the cephalopod diet of southern elephant seal females at King George Island, during El Nino-La Nina events. J Mar Biol Assoc UK 82:913-916

Pierce GJ, Boyle PR, Hastie LC, Santos MB (1994) Diet of squid Loligo forbesi and Loligo vulgaris in the northeast Atlantic. Fish Res 21:149-163

Post DM (2002) Using stable isotopes to estimate trophic position models, methods, and assumptions. Ecology 83:703-718

Pütz K (1995) The post-moult diet of emperor penguins (Aptenodytes forsteri) in the eastern Weddell Sea, Antarctica. Polar Biol 15:457-463

Quetglas A, Alemany F, Carbonell A, Merella P, Sanchez P (1999) Diet of the European flying squid Todarodes sagittus (Cephalopoda: Ommastrephidae) in the Balearic Sea (western Mediterranean). J Mar Biol Assoc UK 79:479-486

Rau GH, Hopkins TL, Torres JJ $(1991){ }^{15} \mathrm{~N}:{ }^{14} \mathrm{~N}$ and ${ }^{13} \mathrm{C}:{ }^{12} \mathrm{C}$ in Weddell Sea invertebrates: implications for feeding diversity. Mar Ecol Prog Ser 77:1-6

Rau GH, Ainley DG, Bengston JL, Torres JJ, Hopkins TL (1992) ${ }^{15} \mathrm{~N}:{ }^{14} \mathrm{~N}$ and ${ }^{13} \mathrm{C}:{ }^{12} \mathrm{C}$ in Weddell Sea birds, seals and fish: implications for diet and trophic structure. Mar Ecol Prog Ser $84: 1-8$

Robertson GG, Williams R, Green K, Robertson L (1994) Diet composition of emperor penguin chicks Aptenodytes forsteri at two Mawson Coast colonies, Antarctica. Ibis 136:19-31

Rodhouse PG (1990) Cephalopod fauna of the Scotia Sea at South Georgia: potential for commercial exploitation and possible consequences. In: Kerry KR, Hempel G (eds) Antarctic ecosystems. Springer, Berlin, pp 289-298

Rodhouse PG, Nigmatullin CM (1996) Role as consumers. Philos Trans R Soc Lond Ser B 351:1003-1022

Schmidt K, Atkinson A, Stübing D, McClelland JW, Montoya JP, Voss M (2003) Trophic relationships among Southern Ocean copepods and krill: some uses and limitations of a stable isotope approach. Limnol Oceanogr 48(1):277-289

Slip DJ, Moore GJ, Green K (1995) Stomach contents of a southern bottlenose whale Hyperoodon planifrons stranded at Heard Island. Mar Mamm Sci 11:575-584

Todd FS, Adie S, Splettstoesser JF (2004) First ground visit to the emperor penguin Aptenodytes forsteri colony at Snow Hill Island, Weddell Sea, Antarctica. Mar Ornithol 32:193-194

Wada E, Terazaki M, Kabaya Y, Nemoto T (1987) ${ }^{15} \mathrm{~N}$ and ${ }^{13} \mathrm{C}$ abundances in the Antarctic Ocean with emphasis on the biogeochemical structure of the food web. Deep Sea Res 34:829-841

Williams TD (1995) The penguins. Bird families of the world. Oxford University Press, Oxford, pp 295

Wilson RP, La Cock GD, Wilson M-P, Mollagee F (1985) Differential digestion of fish and squid in jackass penguins Spheniscus dersus. Ornis Scand 16:77-79

Woehler EJ (1993) The distribution and abundance of Antarctic and subantarctic penguins. Scientific Committee on Anarctic Research, Cambridge

Xavier JC, Rodhouse PG, Purves MG, Daw TM, Arata J, Pilling GM (2002) Distribution of cephalopods recorded in the diet of the Patagonian toothfish (Dissostichus eleginoides) around South Georgia. Polar Biol 25:323-330 